\title{
State of Waste Management and the Willingness of Households to Sort Plastic Wastes before Disposal in Bolgatanga Municipality Bright Buzong Yintii $^{1^{*}}$, Maxwell Anim- Gyampo ${ }^{2}$, Maurice M. Braimah ${ }^{3}$ \\ ${ }^{1}$ Lecturer, School of Applied Science and Arts, Department of Ecological Agriculture, Bolgatanga Polytechnic, Ghana \\ ${ }^{2}$ Lecturer, Faculty of Applied Sciences, Department of Environmental Science, University for Development Studies, Ghana ${ }^{3}$ Lecturer, School of Engineering, Department of Agricultural Engineering, Bolgatanga Polytechnic, Ghana
}

\author{
*Corresponding Author: \\ Bright Buzong Yintii \\ Email: buzong2000@yahoo.com
}

\begin{abstract}
The study was conducted in the Bolgatanga Municipality of Ghana involving 360 household heads. A simple random sampling was used to select the households from 12 randomly selected Electoral Areas out of 47 Electoral Areas. The study shows that $34 \%$ preferred plastic products because of the lack of alternative materials while $53 \%$ and $13 \%$ preferred plastics products because it was common and light in weight respectively. The desire to use plastic products has resulted in high plastic waste generation. Out of the total households of 360, $2 \%$ were not aware that plastics could cause any threat whilst $98 \%$ households were very much aware of the threats caused by plastics. In a multiple response, almost all household within the Municipality agreed that plastic waste created a diversity of problems. 97\% indicated that plastic waste silt gutters, $97 \%$ said plastic waste creates unsanitary environmental conditions, $66 \%$ was of the view that plastic wastes serves as breading grounds for mosquitoes, $60 \%$ said they cause animal death whilst 53\% said they pollute water bodies. Also nearly $50 \%$ indicated that plastic wastes affect human health and $59 \%$ said they affect agricultural soils. The study also revealed that $34 \%$ were not willing to separate plastics waste from household waste before disposal whilst $66 \%$ were willing to do so. The Bolgatanga Municipality and the Zoomlion Company have very little capacity to manage plastic waste in the Municipality. The government and civil society organizations must therefore establish recycling plants in each region to convert the plastic wastes into useful products for the society.

Keywords: State, Waste, Plastics, Management, Households.
\end{abstract}

\section{INTRODUCTION}

According to Spokas [1] and Geographical [2] around 500 billion of plastics bags are used worldwide. Mudgal et al., [3] have noted that global plastics production grew from 1.5 million tonnes $(\mathrm{Mt})$ per annum in 1950 to 245 Million tonnes in 2008. Production of plastic has leveled off in recent years, however, it is not declining and may well increase in the future as applications for plastic increase and its use continues to grow in developing and emerging economies [4]. As plastic consumption is increasing, more and more plastic waste is being generated $[5,6]$. FOEN [7] indicates that, plastics form around $15 \%$ of household refuse and according to a report published in December 2010, the U.S. Environmental Protection Agency (USEPA) determined that, the United States alone generated 30 million tonnes of plastic waste in 2009. It is believed after their entry into the environment, plastics can persist up to 100 years without being decomposed by sunlight and/or microorganisms $[8,9]$. It is usually non-biodegradable and therefore can remain as waste in the environment for a very long time [10] it may pose risks to human health as well as the environment; and it can be difficult to reuse and/or recycle in practice. An issue of particular concern is that, giant masses of plastic waste have been discovered in the North Atlantic and Pacific Ocean; the full environmental impacts of which are not yet fully understood but which cause severe damage to seabirds, marine mammals and fish [10].

As enormous amount of plastic waste is generated throughout the world, the most crucially posed question is how to manage it effectively and efficiently to save the environment and the continuous existence of mankind [11]. Many municipalities, cities and towns the world over continue to grapple with the problem because it imposes negative environmental externalities. In Ghana, most of the concern for plastic waste management is with the urban areas than the rural areas. Urban areas in Ghana produce a variety of these plastic wastes because of the adoption of a more hygienic mode of packaging food, beverages, "iced water" and other products. This has brought plastic 
packaging to replace the existing cultural packaging methods (leaf wrappers, brown paper and metal cup uses) in cities and towns [12-15]. This widespread replacement of the modes of packaging with plastics is an indication of the uniqueness of plastic properties such as versatility, inertness and flexibility, especially in the application areas of packaging. As a result of their unique properties, plastics have become the most favored packaging materials in commerce with firms making windfall profits and transferring the environmental cost associated with cleaning plastic waste on the general public.

The shift to this new form of plastic packaging in Ghana has equally created or generated huge quantities of waste and created pressing sanitation problem as many towns and cities are overwhelmed with management of wastes. According to a study conducted in Accra, Ghana by GOPA Consultants in 1983, Plastic Waste accounted for 1-5\% (of net weight) of the total amount of waste generated [16]. The majority of these wastes are sachet water bags. This is so because, the public have developed a strong taste for such sachet water since it is portable and can easily be carried from one place to another. After gulping down the liquid content, these bags are discarded indiscriminately thereby littering the whole environment. These bags now constitute a major proportion of the plastic waste generated throughout the urban areas in Ghana [11].

Statistics released by the Accra Metropolitan Assembly (AMA) Waste Management Department and other waste management bodies indicated that about 9000 tonnes of waste is generated daily, out of which 315 tonnes are plastic related [17]. Plastic wastes are sent to dumpsites, but majority end up in drains, streams and open places. Some plastic wastes are disposed of by open dumping, open burning, controlled burning and tipping at dumpsites. These methods employed in the management of plastics over the years have only proved unsuccessful. Households are the single largest generator of municipal waste and account for more than $50 \%$ of the total waste in the cities [18]. In some urban area, approximately $80 \%$ of the municipal waste is generated within households of which plastic waste constitutes $25 \%$ [19].

UNEP [20] reported that plastic waste causes the death of up to a million seabirds, 100,000 marine mammals and countless fish through various impacts. This figure according literature is useful in raising awareness and was derived from the scaling up of smaller samples from a study in Canada [21]. Probably a more accurate representation is that compiled by Laist [22], which reported that at least 267 different species are known to have suffered from impacts of plastic waste. This includes 86 per cent of all sea turtle species, 44 per cent of all seabird species and 43 per cent of all marine mammal species [22]. The effects of plastic waste especially bags on animals is also well noted [23]. A study conducted by Ramaswamy and Sharma [24] in Gondar City of Ethiopia, on impacts of plastic bag usage on environment and cattle health, indicated that plastic bags posed several cattle health problems including deaths. Moreover, ingestion of plastic bags (along with other foreign bodies) was reported to cause reduction in milk yield [24]. According to Tiruneh and Yesuwork, [25] and Ramaswamy and Sharma, [22] domestic animals that were most affected were ruminants (cattle, sheep and goats) and dogs. Further research findings have also indicated that reusable plastic bags posed serious human health problems [2628]. The studies showed that reusable plastic bags can become habitats for pathogenic microorganism. Gerba et al., [28] for instance reported that reuse of plastic bags to carry groceries could cause a significant risk of cross contamination of food by pathogenic bacteria such as coliform and E. coli.

Plastic waste contributes to climate change especially when it is burned resulting in the emissions of greenhouse gases [29-31]. There is also release of toxic organic compounds into the environment that cause different health risks, such as respiratory health problems [32, 33]. Plastic waste especially polyethene bags deteriorates the natural beauty of the environment as a result of indiscriminate and open dumping of waste by people $[32,34,35]$. Deterioration of natural beauty of the environment by plastics have been confirmed by Mangizvo [36] and Adane and Muleta [23] as a problem associated with plastic wastes. These observations are consistent with reports on environmental problems of plastic bag wastes in other countries [37]. In Ghana, deterioration of environment by plastics has also been noted by Anomanyo [39].

Another problem of plastic waste that has to do with their ability to block drain systems resulting in flooding any time it rained [23]. This has been supported by Seema, [35], Boadi and Kuitunen, [32], Smith, [40] in a report on consequence of blockade of sewerage systems by plastic bag wastes. Moreover, the blocked storm drains also created pools of stagnant water, allowing mosquitoes and other insects to breed more easily within a city, and transmit a variety of lethal diseases such as dengue, malaria, yellow fever and several forms of encephalitis [32, 33, 41].

\section{Problem Statement And Relevance Of The Study}

The Bolgatanga municipality like any other urban area in Ghana is also battling with the issue of waste especially plastic waste. The Municipal is engulfed with filth as a result of plastic waste disposal. Plastic waste is often deposited in unauthorised places like gutters, open places within residential and market areas, around waste containers and along the roadside. When these plastic wastes are collected and taken to 
dumping sites by waste management bodies, it is believed that it is not properly managed. They are often left in piles for weeks and later set on fire which in turn generates toxic gases that could be dangerous to inhabitants of a location and the environment. In addition when wind blows or during the rainy season some of these plastic materials are brought blown or washed back into neighbouring communities. Furthermore, the inappropriate disposal of these plastic waste especially where they turn to choke gutters promotes flooding during rains. Some choked gutters and small plastics containers such as margarine and pomade containers collect rainwater and serve as breeding sites for mosquitoes. The current environmental situation in Bolgatanga Municipality indicates that the Assembly together with Zoomlion (the only private waste management firm in Bolgatanga) are unable to cope with the problem and needs the support of households in waste separation before disposal. The Bolgatanga Municipal Assembly and the government of Ghana at large have challenged plastic manufactures and importers to provide alternative ways for disposing waste or face a ban on plastic manufacturing and importation. The singular effort of households would enhance waste reduction, recycling and reuse which are essential in effective waste management. The paper therefore sought to investigate the willingness of households to practice waste separation before disposal in the Bolgatanga Municipality. Specifically, the paper would assess the current waste management situation in Bolgatanga Municipality; investigate the threats associated with poor plastic wastes management in the Bolgatanga Municipality and finally examine the willingness of households to separate plastic from household waste before disposal.

\section{Study Area}

The Bolgatanga Municipality is located in the center of the Upper East Region between latitude $10^{\circ}$ $47^{\prime} 50^{\prime \prime} \mathrm{N}$ and Longitude $0^{\circ} 52^{\prime} 40^{\prime \prime} \mathrm{W}$. It has a total land area of $729 \mathrm{sq} \mathrm{km}$ and is bordered to the North by the Bongo District, South and East by Talensi-Nabdam District and Kassena-Nankana East and West Districts to the West.

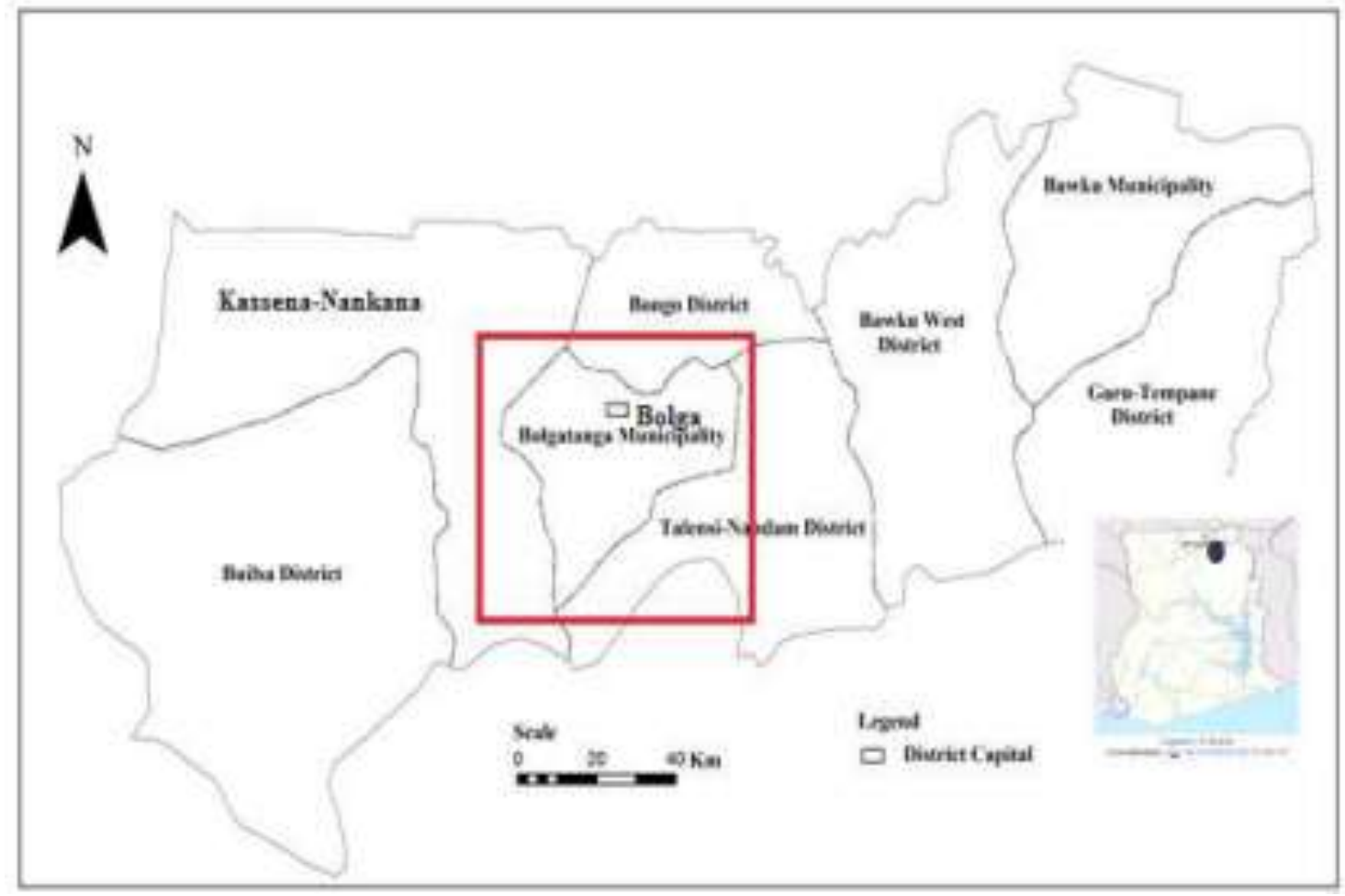

Fig-1: Map of the Bolgatanga Municipality

The majority of the inhabitants of the Municipality are from northern ethnic origins with the indigenous inhabitants of the area being the Grunes. Other settlers mainly in the Bolgatanga Township include the Akans, Ewes, Ga-Adanbge. These have come into the Town because of its regional capital status. Most of these ethnic groupings are organized around chiefs and elders, whiles others come together as social grouping.
The Family is the basic social grouping among the people. There is the nuclear and the extended Family. The Family and the traditional system of Government serve as the rallying point for Community participation in developmental activities and social action. 
The People have two Festivals; the Adakoya celebrated by the people of Bolgatanga after the farming season and the NabaYesika celebrated by the people of Sherigu to outdoor their Chief. Agriculture is the main occupation of the People.

\section{Climate And Vegetation}

The climate is classified as Guinea Savannah Zone with a single rainy season in a year that runs from May to October. The long dry season stretches from October to April, with hardly any rains. Mean annual rainfall is $950 \mathrm{~mm}$ while maximum temperature is $45^{\circ} \mathrm{C}$ in March and April with a minimum of $12^{\circ} \mathrm{C}$ in December. The one rainy season means most Agricultural activities must be carried out at this time to get the food requirements for the year. As this is normally not achieved, this has to be supplemented with irrigation farming in the dry season. The natural vegetation is that of Guinea savannah woodland consisting of short deciduous trees, widely spaced and a ground flora, which gets burnt by fire or scorched by the sun during the long dry season. The most common economic trees are the Shea-nut, dawadawa, baobab and acacia. The Municipality has a forest reserve, which primarily protects most of the water bodies in the area. There is high incidence of bush fires because of the drying up of the ground flora during the dry season which sometimes burns some of these economic trees.

\section{Topography And Drainage}

The municipality generally has gentle slopes ranging from $1 \%$ to $5 \%$ with some isolated rock outcrops and some uplands which have slopes over $10 \%$. The main rivers are the White Volta, Red Volta, and their tributaries [42].

\section{Geology And Soil Types}

The Municipal falls within the Birrimian rocks of Ghana. Minerals Deposits includes gold and manganese is found along Kalbeo and Sherigu areas. Large deposits of clay are found throughout the Municipality around Zaare, Gambigbo, Yikine and Kalbeo.

Most of the soils in the Municipality are developed over shale, which contains abundant iron concretions and iron pan in their sub-soils. These soils constitute the groundwater laterite and occupy about $50 \%$ of the interior savannah. The groundwater laterite, due to impervious iron pan or clay pan in the sub-soil, is characterized by water logging at the peak of the rains and the resultant perennial floods around August and September which are the peak of the rainy season.

The soils are quite good along the valleys. Alluvial valleys are quite extensive and suitable for rice production. There is considerable soil erosion in the district becoming severe around most of the valleys. This is due to bad farming practices and rampant burning of bush.

\section{Demographic Characteristics}

The population of the Bolgatanga Municipality according to the 2010 population census is 131,550 . The sex distribution of Males and females are 62,783 $(48 \%)$ and $68,767(52 \%)$ respectively. The total household numbers of the municipal stands at 26,706.There are about 213 communities in the Municipality. The settlement pattern is predominantly rural (about 95\%) with dispersed buildings.

\section{METHODOLOGY \\ Secondary data collection}

The researcher obtained secondary data from books, articles, newspapers and the internet for review of literature. Data gathered from the Municipal Assembly included their coverage area in terms of waste management; the final destination of all waste gathered from the municipality as well as challenges confronting them. Data gathered also included Assembly's partners in waste management. Data gathered from Zoomlion included waste flow in the Municipality as well as its coverage area in terms of percentages. Other secondary data gathered from both the Assembly and the Municipal Assembly include household waste management practices.

\section{Primary Data collection}

The researcher used stratified multistage sampling, simple random sampling and convenience sampling. Direct observation was also employed to document the actual household waste management situation on the ground.Considering the time and resources available it was not possible to carry out the study in all the Electoral Areas. Simple random sampling was therefore used to select 12 out of the 47 Electoral Areas as the study site. These are; Atulbabisi, Bukere, Dapoore-Tindongo, Kotokoli-Zongo, Kumbosgo, Soe, Tindonsoligo, Tanzui-Zobisi, Tindonmolgo, Zaare, Yekene and Yarigabisi. Within each of the selected EA's a total of thirty households were interviewed. Houses were randomly selected and at least one member of each household was interviewed for convenience.

\section{Questionnaires administration}

The main data collection tool was the structured and semi-structured questionnaire which was used in interviewing the householders. A total of 360 questionnaires were self-administered to collect indepth household information including demographic data, methods of waste management, level of awareness on plastic waste, problems of plastic waste as well as household roles with regards to the reduction of plastic waste. Question asked were both closed and opened type depending on the information required.

Data Processing and Analysis 
Data gathered through the questionnaire administration was checked for completeness, accuracy and consistency of responses in order to identity and eliminate errors. The data was then entered into the computer using Epinfo version 3.1; a data entry software and then processed with Statistical Package for Social Sciences (SPSS) into statistical tables and charts for interpretation and further discussions.

\section{RESULTS AND DISCUSSION}

\section{Demographic Characteristics of Respondents}

Out of the total sample size of 360, 217 (60\%) of them were females and whilst $143(40 \%)$ were males. The study indicates that $56 \%$ of the respondents were not married, whilst $37 \%$ were married couples. However, less than $6 \%$ of the respondents fell into other categories either than single and married couples with a $1 \%$ non-response rate. The study sample randomly included $49 \%$ of students leaving in the study communities, $25 \%$ of the respondents were operating private businesses whilst $17 \%$ were in the civil service category. However, $9 \%$ of the respondents included in the study sample were unemployed. The percentage of respondents who had no education was $7 \%$, tertiary $(47 \%)$, secondary $(37 \%)$, primary $(5 \%)$ and vocational education $(4 \%)$. Out of 360 respondents, 257 were Christians whilst 95 were Muslims. 8 respondents however belonged to other religion.

\section{Waste Management Situation in Bolgatanga Municipality}

Waste management in the Bolgatanga Municipality is carried out by the Municipal Assembly and Zoomlion Ghana limited. Currently, waste collection is carried out by Zoomlion Ghana limited alone because the Municipal Assembly waste truck had broken down. Plastic waste generated in the Municipality is disposed together with other household waste. Plastics waste originating from households forms the majority of waste within the solid waste stream. Both the Municipal Assembly and Zoomlion Ghana limited dumps all waste collected from the Bolgatanga Municipal at Sherigu in a crude form.

There are no plastic recycling firms in the Bolgatanga Municipality. However, certain individuals have taken it upon themselves to collect some types of plastics not because they want to reduce the amount of plastic waste in the environment but because of economic purposes. Some in the Municipality encourage children to collect pure water sachets and other forms of polythene to be woven into school bags for them. Because of this it is very common to see children in some parts of the Bolgatanga Township busily collecting these plastic products. There are others who are interested in plastic products such as broken chairs, cups, bowls and gallons. These they obtain by going from one dumpsite to another in order to collect them. Some people voluntarily also give their old plastic chairs, cups, gallons and bowls out while others sell them out to the waste collectors. According to one waste collector, a broken plastic chair sells between 1.0 Ghana cedis and 1.50 Ghana cedi while a kilo of broken plastics cups and bowls sells for 0.04 Ghana cedis. An old gallon weighing 1kilo also sells for 0.40 Ghana cedis. It is probably because of the economic value attached to these categories of plastic products that has resulted in their lesser numbers in the environment as compared to pure water sachets and polythene bags. In Bolgatanga Municipality, there are no systems for picking plastic waste because of the absence of recycling plants. Obtaining 1kilo of pure water sachet or polythene can be very hectic and for that matter waste collectors concentrate on the plastic products such as the chairs, cups, gallons, bowls as already mentioned above. This has therefore reduced the interest in pure water sachets and polythene bags by the waste collectors thus their numbers increasing in the environment. When the plastic waste collectors have gathered enough harder plastics, they are crashed by a machine into smaller pieces, sieved, sorted and package in sacks to allow easier transportation to Accra where they are used to produce new plastic products.

A household reason for using plastic products is paramount in effective management of plastic waste. Households within the Bolgatanga Municipality preferred plastic products for a number of reasons. The study shows that $34 \%$ preferred plastic products because of the lack of alternative materials while $53 \%$ and $13 \%$ preferred plastics products because it was common and light in weight respectively. Generally however, households preferred plastics products because they were virtually cheap compared to other similar products made of different material other than plastics. These reasons for people's preference of plastic products have also been observed by the European Commission [10]. According to the European Commission [10], general preference of plastic products lies in the fact that they are relative cheap, versatile and durable materials. Similar observations have been made by Adane and Muleta [23] in Jimma City in Ethiopia and Mangizvo, [36] in Alice, South Africa. The findings are also consistent with other reports describing that light weight, cheap price, excellent fitness for use and resource efficiency as main reasons for widespread use of plastic bags by billions of customers worldwide [29].

Knowledge of the types of plastics brought into the household is very important because, it can inform management to use appropriate methods to effectively deal with the various types of plastics introduced into the household. Respondents indicates that majority of the plastic products brought into the household were polythene bags and pure water sachets. The situation was so because, most of the households had a preference for pure water because it is believed to 
be treated and well packaged. Even in homes where taps were available, households said they still preferred purchasing pure sachet water as drinking water. In addition, almost everything bought in the market or supermarket is virtually wrapped in a polythene bag hence these two formed the majority of plastics introduced into the households. In terms of rate of introduction, these products are also introduced into the household at a very faster rate and subsequently disposed at a faster rate, hence forming majority of the plastic waste originating from households. The Municipal Assembly also agreed to the fact that, the pure water sachet and the polyethene bags formed majority of the plastic waste originating from household.

According to the World Bank, [5], every year 500 billion to one trillion of the plastic bags are manufactured and used worldwide and this results in a proportionate rise in plastic waste in the Municipal Solid Waste streams in large cities in sub-Sahara Africa. Mangizvo, [36], also observed that plastic bags used among inhabitants of South Africa have increased despite legislation by the government to ban its production and use. Jimma City of South Eastern Ethiopia, Adane and Muleta [23] made similar observations whereby; out of the 230 respondents, (77\%) used plastic bags in high frequency as compared to other plastics products. The observation of more plastic bags (polyethene bags) in households of the Bolgatanga Municipality is consistent with the report of Ramaswamy and Sharma, [24] among the residents of Gondar City in Ethiopia. The increase use of plastic bags lies in the fact that modern society shows a high preference for it Li et al., [43].

\section{Threats Associated with Poor Plastic Wastes Management}

Households view on the effects of plastics can be a determining factor in the way households handles plastic products and the waste arising after consumption. Out of the total households of $360,2 \%$ were not aware that plastics could cause any threat whilst $98 \%$ households were very much aware of the threats caused by plastics. This is an indication that, majority of households in the Municipality are actually aware of the effects of plastic and for that matter should have reflected in the manner they handle their household plastic waste. The current plastic waste situation simply means that despite households knowing plastics can be dangerous, they are not putting more efforts to properly dispose the waste. Several literatures exist to support people awareness of the possible effects of plastic waste [32, 34, 35, 44, 45]. Based on their response, it was paramount to ascertain whether they actually knew the type of threats it possess.

In a multiple response, almost all household within the Municipality agreed that plastic waste created a diversity of problems including chocking of gutters (350, 97\%), creation of unsanitary environmental conditions (97\%), forming breading grounds for mosquitoes (66\%), causing animal death $(60 \%)$, polluting water bodies $(53 \%)$, affecting human health $(50 \%)$ and Agricultural soils (59\%).The trend observed in the Bolgatanga Municipality is similar to other cities of developing countries [34]. With regards to impacts of plastic bags, a similar research by Adane and Muleta, [23] revealed the following; animal death $(73 \%)$, blockage of sewage system $(70 \%)$, deterioration of natural beauty of environment $(63 \%)$ and human health problems (52\%). Anomanyo, [38] observed that accumulation of plastic waste especially plastic bags causes environmental pollution resulting in deterioration of natural environment. Other literature confirming this are UNEP, [37] and in Ghana by Anomanyo [38]. The effects of plastic waste on drainage systems are also well established by the following; Seema, [35]; Boadi and kultunen [32]; Smith, [40]. According to Smith, [40], the 2005 Mumbai flooding incidence that killed over 1000 people and at least 1000 animals and livestock was attributed to plastic bags clogging the city's drainage system, thus preventing the monsoon rains from leaving the city. When plastic bags or container collects water or traps water in drainage system they serve as breeding grounds for mosquitoes [40, 46].

Impacts of plastics waste on animals have been observed by Ramaswamy and Sharma, [24] in Gondar City where cattle were affected. In that same study ingestion of plastic bags reduce milk production in cattle. In severe cases the animals dies [42, 47, 48]. Thiel[49]; UNEP, [20] and Laist, [22] observed that plastics waste had negative impacts on marine animals such as marine birds, turtles, seals and Whale. It is not impacts on only animal that have been well established but impacts on humans as well. In a report reuse of plastic bags can cause contamination of food by microorganism [26-28].

Areas that received door-to-door services of solid waste management services included the Tindonsobligo (SNNIT area) and some parts (newly developed areas) of Zaare (Hospital area), Yarigabisi (new developing areas) and Yekene. It is therefore very obvious that the coverage of indoor waste management services is limited and more to the point some household simply did not want to benefit from door- todoor services due to the supposed high charges and inefficiencies such as the irregular collection of waste as opposed by Puopiel [50] where most homes were not interested in the door-to-door services because of inefficiencies. 


\section{Willingness to Separate Plastic Waste from Household Waste before Disposal}

In countries where plastic waste management especially recycling has been effective, households have played important roles in the area of sorting or separating plastics from other household waste. The importance of sorting of plastics at both the point of generation and the point of recycling have been observed in Accra. In the Bolgatanga Municipality, there are virtually no recycling firms as confirmed by respondents however, households were willing to separate plastics from other household waste only if they will get some direct benefits or were aware of recycling firms. Out of a total of 360 households, 122 $(34 \%)$ indicated that they were not willing to separate plastics waste from household waste before disposal whilst $236(66 \%)$ were willing to do so. The result is consistent with Oyake-Ombis [51] who observed that a profound large size of respondents (72\%) affirmed their willingness to separate waste generated in Kenya. Those who respondent otherwise were $22 \%$ and the rest $(6 \%)$ did not respond to the questions on this attribute.

\section{CONCLUSION}

The Bolgatanga Municipality and the Zoomlion Company have very little capacity to manage plastic waste in the Municipality. At the moment, only the Zoomlion Company has trucks to convey waste to the waste dump at Shrigu. Unlike other Municipalities in Ghana, there are no systems in place to clear the Municipality of plastic waste and recycling plants are non-existent. Those who pick plastic waste in the Municipality sell them to recycling plants cited in Southern Ghana. Since they are not paid for collecting the plastic waste and the avenues for recycling plants are inadequate in the country, they are not motivated to collect them. It is therefore possible that plastic waste in the Municipality would continue to accumulate.

Also indiscriminate disposal of plastic waste in the Municipality has resulted in choked gutters leading to flooding during flood periods. Pools of water collected by plastic waste breed mosquitoes and the incidence of malaria in the Municipality continues to increase despite interventions by the central government. Plastic wastes which are salty and generated after eating packaged foods are eating by domestic animals and they suffocate to death causing economic loss. Households are willing to separate or sort plastic waste before disposing their waste. They must therefore be encouraged by paying a token for their efforts. This effort together with those who collect plastic waste for sale would result in a cleaner Municipality.

\section{RECOMMENDATIONS}

The researcher sees it necessary to make the following recommendations for authorities to consider in addressing the plastic waste problem in the Bolgatanga Municipality:

\section{Public awareness and education campaigns}

The creation of awareness among households and all in society regarding indiscriminate use and disposal of plastic bags will be a good option to overcome the problem in future. Even though households are already aware of the impacts of plastics such awareness and educational campaigns must still be carried to remind people continuously. This could be done through anti-littering campaigns and promotions where residents are educated on the dangers posed by plastic bags. Awareness campaigns should be used to encourage behavioural change on plastic bag use. It is important to educate the public on the ills of plastic bags and ensure that information on the possible safe alternatives is available. There are already numerous alternatives to plastic shopping bags which include paper bags, green bags and degradable bags.

\section{Support for the Bolgatanga Municipal Assembly}

The Bolgatanga Municipal Assembly should be supported especially in the area of skip trucks since the numbers of communal dumpsites are many. One skip truck for the Assembly is woefully inadequate. As at the time this research was conducted, the Municipal Assembly had its skip truck broken down and was dependent on the one used by Zoomlion Ghana Limited. The private waste management firm could only extend a helping hand after it had finish with it territory.

\section{Establishing recycling facilities in the Bolgatanga Municipality}

Once plastic waste is common and forms majority of waste in the municipal waste stream and the largest generated by households in many urban areas, there is the need to establish recycling facilities to recycle waste. It should be the priority of government to at least ensure there is a recycling firm in all the ten regions of Ghana to reduce the stress people go through in carrying plastic waste from other region to Accra, Kumasi and Takoradi where some recycling facilities exist. This move is possible if only households are encouraged to sort their plastic waste at the household level.

\section{REFERENCES}

1. Spokas, K.A. (2007). Plastics: still young, but having a mature impact. Waste Manage., 28(3): 473-474.

2. Geographical, (2005). "Waste: An Overview." Geographical, 77(9): 34- 35.

3. Mudgal, S., Lyons, L., Bain, J. et al., (2011). Plastic Waste in the Environment - Revised Final Report for European Commission DG Environment. Bio Intelligence Service. Downloadable from 
http://www.ec.europa.eu/environment/waste/studie s/pdf/plastics.pdf

4. Global Industry Analysts, (2011).Molded Plastics: A Global Strategic Business Report.Global Industry Analysts Inc. Obtained on the internet: http://www.prweb.com/releases/molded_plastics/H DPE_LDPE_PVC/prweb8075824.htm

5. World Bank, (1996).Urban Environmental Sanitation Project, Staff Appraisal Report, Republic of Ghana, Africa Regional Office.Washington.

6. Yankson, P. W. K. (1998). The Urban Informal Economy Accommodation, Growth, Linkages, Health and Environmental Impact.The Case of Greater Accra Metropolitan Area (GAMA). Ghana University Press, Accra.

7. The Situation, Forest, timber, game, natural hazard (2003).Federal office of FOEN. [Available on www.bafu.admin.ch/publikationen/publikaton/0076 3/index.html?lang=en]

8. Stevens, E. (2001). Green Plastics: An introduction to the new science of biodegradable plastics. Princeton, NJ: Princeton University Press, pp.1530.

9. United Nations Environment Programme (UNEP), (2005a). Plastic bag ban in Kenya proposed as part of a new waste strategy. UNEP press release.

10. European Commission DG ENV (2011). Plastic waste: Ecological and human health impacts [Available on: http://webcache.googleusercontent.com/search?q=c ache:dN9mJqFIRaoJ:ec.europa.eu/environment/int egration/research/newsalert/pdf/IR1.pdf $+\& c d=1 \&$ h $\mathrm{l}=\mathrm{en} \& \mathrm{ct}=\mathrm{clnk} \& \mathrm{gl}=\mathrm{gh} \& \mathrm{client}=$ firefox $-\mathrm{a}]$

11. Wienaah, M., (2007).Sustainable plastic waste management - A case of Accra, Ghana. http://www2.1wr.kth.se/Publikationer/PDF_Files/L WR_EX_07_10.PDF [Accessed $2^{\text {nd }}$ July 2012].

12. Adarkwa, K. K. and Edmundsen A. R. (1993).Urban Waste Management in Ghana, a Study of Eleven Urban Centers.University of Science and Technology, Kumasi.

13. KMA,(1995).Strategic Sanitation Plan for Kumasi 1996-2005. Kumasi, Ghana

14. World Bank,(1995).Ghana, Growth, Private Sector, and Poverty Reduction, a Country Economic Memorandum. Washington D.C.

15. Schweizer F. and Annoh C. K. (1996). Privatization of Solid Waste Management in Ghana, Trialog48: 50. A thesis submitted to the University of Science and Technology in partial fulfilment of the requirement for the degree of Master of Science in Development policy and planning.

16. Lardinois, I. \&Klundert van de, (1995). Plastic waste.Options for small scale resource recovery.Urban Solid Waste Series 2.Waste consultant.
17. Amankwah, A. (2005). Plastic Waste Wahala.[Access on 08 June, 2006 from http:www.ghanaweb.com/publicagenda/arcticle]

18. Sarkhel, P. (2006). Economics of household waste management in Kolkata: propose steps towards improved efficiency. Http://www.google.com.gh/search?Q=HOUSEHO LDS+AND+PLASTIC+WASTE+MANAGEMEN T\&btng=Search\&oe $=$ utf-

$8 \&$ rls=org.mozilla\%3Aen-

US\%3Aofficial\&client=firefoxa $\quad\left[\right.$ Accessed $22^{\text {nd }}$ July, 2012]

19. Practical Action, (2005) Re-thinking plastics, declogging the Globe Environmental Sanitation, (10) pp. 12.

20. UNEP, (2006).Ecosystems and Biodiversity in Deep Waters and High Seas.UNEP Regional Seas Reports and Studies No. 178.UNEP/ IUCN, Switzerland 2006. ISBN: 92-807-2734-6.

21. National Oceanic and Atmospheric Administration (NOAA) (2010). Plastic Marine Debris; What We Know. Downloadable from http://marinedebris.noaa.gov/info/plastic.html

22. Laist, D. W., (1997). Impacts of marine debris: entanglement of marine life in marine debris including a comprehensive list of species with entanglement and ingestion records. In: Coe, J.

23. Adane, L. and Muleta, D. (2011). Survey on the usage of plastic bags, their disposal and adverse impacts on environment: A case study in Jimma City, Southwestern Ethiopia.Journal of Toxicology and Environmental Health Sciences Vol. 3(8) pp. 234-248.

24. Ramaswamy, V. and Sharma, H.R. (2011).Plastic bags - threat to environment and cattle health: a retrospective study from Gondar City of Ethiopia. The IIOAB Journal: special issue on Environ. Manage. Sustain. Develop. 2(1): 7-12.

25. Tiruneh, R. and Yesuwork, H. (2010). Occurrence of rumen foreign bodies in sheep and goats slaughtered at Addis Ababa Municipal Abattoir. www.oalib.com/papere/133654\#.uwnRfsw40 [Accessed June 2012)

26. Cliver, D.O. (2006). Cutting boards in Salmonella cross-contamination.JAOAC Int., 89: 538-542.

27. Maule, A. (2000). Survival of verocytotoxigenicEscherichia coli O157 in soil, water and on surfaces.Symp. Ser. Soc. Appl. Microbiol., 29: 71S-78S.

28. Gerba, C.P., Williams, D., Sinclair, R.G. (2010). Assessment of the potential for cross contamination of food products by reusable shopping bags.Obtained through internet: http.uanews.org [Accessed on 26 August, 2010].

29. Verghese, K., Jollands, M., Allan, M. (2006). The Litterability of plastic bags: Key design criteria. A report presented on 5th Australian Conference on Life Cycle Assessment: Achieving business 
benefits from managing life cycle impacts, Melbourne, pp. 1-10.

30. Muthu, S.S., Li, Y., Hu, J.Y., Mok, P.Y. (2011). An exploratory comparative study on eco-impact of paper and plastic bags. J. Fiber Bioeng. Inf., 1: 307-320.

31. Pilz, H., Brandt, B. and Fehringer, R. (2010).The impact of plastics on life cycle energy consumption and greenhouse gas emissions in Europe. Summary report by denkstatt for Plastics Europe.

32. Boadi, K.O., Kuitunen, M. (2005). Environmental and health impacts ofhousehold solid waste handling and disposal practices in third worldcities: the case of the Accra Metropolitan Area, Ghana. J. Environ.Health, 68(4): 32-36.

33. Rayne, S. (2008). The need for reducing plastic shopping bag use and disposal in Africa. Afr. J. Environ. Sci. Technol., 3: 1-3.

34. Girum, B. (2005) Sustainable management of plastic bag waste. The case of Nairobi, Kenya.Lund, Sweden, pp. 3-52.

35. Seema, S. (2008).Ecologically oriented behavior in consumers (Report).Abhigyan.Foundation for Organizational Research and Education, the Gale Group, Farmington Hills, Michigan, USA.

36. Mangizvo, R. V. (2012). The Incidence of Plastic Waste and their effects in Alice, South Africa. Journal of Social Sciences Research; 2(1): 49-53,

37. United Nations Environment Programme (UNEP) (2005b). Report on employing economic instruments in solid waste management in Kenya, UNEP, New York, USA,

38. Anomanyo, D.E. (2004). Integration of Municipal Solid Waste Management in Accra,

39. Ghana: Biofactor treatment technology as an integral part of the management process. Presented to Lund University, Sweden.

40. Smith, L.C. (2009). Paper or plastic? The economic implications of plastic carrier bag legislation in the United States. A Thesis presented to the faculty of the Department of Economics and Business, The Colorado College, In Partial Fulfillment of the Requirements for the Degree Bachelor of Arts, pp. 34-36.

41. Ellis, S., Kantner S, Saab A, Watson, M. (2005). Plastic grocery bags: The ecological footprint. Environmental changes are spreading infectious diseases-UN study, Victoria, pp. 1-19.

42. Edwards, R. (2000). "Bags of rubbish." The Ecologist, 30(8): 52. Draft 2010-2013 District Medium Term Development. (2010)

43. Li, Y., Muthu, S.S., Hu, J.Y., Mok, P.Y., Ding, X. and Wang, L. (2010). Eco-impact of shopping bags: consumer attitude and governmental policies. J. Sustainable Dev., 3(2): 71-83.

44. Butte Environmental Council, (2001). "Reducing plastic waste tops 2001 legislative agenda." Environmental news (Spring).
http://www.becnet.org/ENews/01sp_plastic.html, p. 10.

45. Lane, M. (2003). "Why Can't We Recycle All This Plastic?" BBC News September 19. Accessed on December 2010.http://news.bbc.co.uk/1/hi/magazine/3116318 .stm.

46. Aziegbe, F.I.(2007). Seasonality and Environmental Impact Status of Polyethylene (Cellophane) Generation and Disposal in Benin City, Nigeria. J. Human Ecol. 2007; 22(2): 141 147.

47. World Watch (2004).'The ubiquitous plastic bag.World Watch.17(1) preceding 1.

48. Forum for Environment (2010). Assessment of the solid waste management System of Bahirdar town and the gaps identified for the development of an ISWM plan, Bahirdar, Ethiopia, p. 10.

49. Thiel, M., Hinojosa, I., Vásquez, N. and Macaya, E. (2003)."Floating Marin Debris in Coastal Waters of the SE-Pacific (Chile).Marine Pollut. Bull. 46: 224-231.

50. Puopiel, F. (2010). Solid waste management in Ghana: The case study of Tamale Metropolitan Area. A master's thesis submitted to the department of planning, Kwame Nkrumah University of Sceince and Technology.

51. Oyake-Ombis L. (2009). Household Perspectives of Innovative Plastic Waste Management in Kenya: Perceptions, Practices and Linkages [Available on: http/www.kadinst.hk/sdconf10_pdf/p41.pdf] 